\title{
Digital Literacy Competencies of Mechanical Engineering Vocational Education Teacher Candidates
}

\author{
Setuju $^{a}$, Herman Dwi Surjono ${ }^{b}$, Dwiningrum ${ }^{c}$, S.I.A, Bruri Triyonod, Ali Muhtadi ${ }^{\mathrm{e}}$, Asri \\ Widowatis \\ a'Universitas Negeri Yogyakarta, Indonesia (ORCID: 0000-0003-4765-9067) \\ bUniversitas Negeri Yogyakarta, Indonesia (ORCID: 0000-0002-2720-2206) \\ 'Universitas Negeri Yogyakarta, Indonesia (ORCID: 0000-0001-6377-6074) \\ dUniversitas Negeri Yogyakarta, Indonesia (ORCID: 0000-0001-5720-9604) \\ fUniversitas Negeri Yogyakarta, Indonesia (ORCID: 0000-0002-3725-7657) \\ 'Universitas Negeri Yogyakarta, Indonesia (ORCID:
}

Article History: Received: 10 November 2020; Revised 12 January 2021 Accepted: 27 January 2021; Published online: 5 April 2021

\begin{abstract}
The era of the Industrial revolution 4.0 collaborates on cyber technology and automation technology. Rapid changes due to the 4.0 industrial revolution, require anticipatory steps by the government through increasing the quality of education. Preparing a great generation who has competencies as capital to anticipate the 4.0 industrial revolution, the 21 st-century learning education. One of the competencies expected for 21 st-century learning is digital literacy skills. Therefore, this study aims to determine the ability of prospective teachers prepared by the Mechanical Engineering Vocational Study Program, Sarjanawiyata University. The population of prospective teachers is students who have implemented teaching practices in schools in the 2019/2020 school year. Quantitative research with descriptive method approach. Data analysis with the percentage of students who use and integrate Information and Communication Technology (ICT) in learning during practical field experience (PPL). The results obtained conclude that digital literacy skills need to be improved, because students in their learning rarely $(50 \%)$ use and integrate ICT in learning. Because with digital literacy skills students can design learning that facilitates students to think critically, creatively, and innovatively.
\end{abstract}

Keywords: digital literacy skills, preservice teacher-student.

\section{Introduction}

The era of the Industrial revolution 4.0 collaborates on cyber technology and automation technology. The concept of the application is centered on the concept of automation carried out by technology without requiring human labor in the application process. Of course, it is necessary to prepare reliable Human Resources (HR) to face this era. Efforts to prepare human resources are closely related to the education sector. Education is the sector that is considered most responsible for preparing young people for their future, regardless of its form. In connection with the rapid changes due to the 4.0 industrial revolution, it is necessary to take anticipatory steps by the government by increasing the quality of education.

The Indonesian nation from 2020 to 2035 will get a demographic bonus because the portion of the productive population is more than the number of non-productive people, in other words, the "dependency ratio" is estimated to be in the lowest category so far, around 44\%, especially in 2030 . However, the demographic bonus can it will turn into a demographic disaster if it is wrong to organize and implement quality education. The challenges that will be faced by Vocational High School (SMK) teachers are analyzed from the Long-Term National Education Development Plan (RPPNJP), the SMK development roadmap from the Directorate of Vocational Education, MP3EI (Master Plan for the Acceleration and Expansion of Indonesian Economic Development) and technological developments that have an impact on the world of education, namely 21 st-century skill needs. namely ICT-based education and based on APEC, the skill needs of the 21st century are (1) learning and innovation skills; (2) information, media and technology skills and (3) life and career skills. Trilling \& Fadel digital literacy skills detailed three literacies including information literacy, ICT literacy, and media literacy. (Trilling \& Fadel, 2009). Utilizing information and communication technology for the interests of learning. is a professional competence for teachers \& Utilizing information and communication technology for self development. (Darma, S. et.al (2013) 
The mechanical engineering vocational education study program is tasked with preparing prospective teachers who have scientific competence in the field of engineering and can design, implement, and evaluate mechanical engineering learning creatively, innovatively, reflectively, critically, and adaptively to the development of ICT (Information and Communication Technology). Therefore, to see whether the prospective teachers who are prepared already have digital literacy competencies, it can be seen when students carry out learning practices in schools. How big are the students in implementing or integrating digital literacy competencies during learning practices in schools? Digital literacy is the ability to access, manage, understand, integrate, communicate, evaluate, and create information safely and appropriately through digital devices and networked technologies for participation in economic and social life. It includes competencies that are variously referred to as computer literacy, ICT literacy, information literacy, and media literacy. (Unisco, 2018).

Digital literacy skills are a highly expected need to answer the challenges of the digitalized era. The Covid 19 outbreak that has hit throughout the world has made rapid changes in the use of information technology. Almost all fields or aspects make use of information technology. The world of education with the existence of Covid 19 by adopting a learning policy implemented online or distance education. Therefore digital competencies make the key to success in implementing digital-based programs. Literacy of representation includes how technology can be understood in our time, and how to use digital tools in a broader context. (Johannesen, 2014).

In considering the nature of general digital competence, comment that: digital competency involves more than knowing how to use devices and applications, which is intricately connected with skills to communicate with ICT, as well as information skills. Sensible and healthy use of ICT requires particular knowledge and attitudes regarding legal and ethical aspects, privacy, and security, as well as understanding the role of ICT in society and a balanced attitude towards technology.(Janssen, at.al, 2013).

Aspects of digital competence that must be possessed by prospective teachers (1) Information literacy includes access, evaluation, use, management; (2) ICT Literacy: integrating ICT in learning, Information: identity, locate, retrieve, store, organize and analyze digital information, judging its relevance and purpose. (Janssen, at.al, 2013). (3) Media literacy: design, use, develop, evaluate according to needs in learning. The digital abilities possessed by educational candidates will be better prepared to face 21 st-century learning so that teachers can prepare graduates who have the expected competencies.(Masitoh, 2018). Examines digital literacy as an effort to improve the quality of learning and towards the golden generation of 2045, and the results of his research work can be concluded that teachers and lecturers in the 21 st century are challenged to be able to prepare learning components that can improve school literacy.

The advancement of digital devices or technology as the identity of the industrial era 4.0 provides opportunities for humans to increase productivity or develop themselves, organizations or communities with specific goals. 21st century teachers are required to be able to manage modern technology in order to support the learning process. Digital devices have become one of the key instructional technologies in education, especially in light of what we know about today's learner. These devices, including the computer, play multiple roles within the curriculum, ranging from tutor to student creativity resource. Teachers can use the computer as an aid to collect student performance data, as well as to manage classroom activities. (Smaldino, 2019). Teacher professional competence related to knowledge deepening approach includes the ability to manage information, solve structural problems, and integrate open software and subject-specific application by method student-centered teaching and projects collaborative in supporting understanding students are the key to their completion complex in the real world. To support collaborative projects, teachers must use network and web-based resources for help students collaborate, access information. (Munir,2014).

\section{Method}

This research approach uses quantitative research with descriptive research methods. Descriptive research is designed to obtain information about the status of symptoms at the time of the study.. The population of this study was all students of the Mechanical Engineering Vocational Study Program of the Sarjanawiyata Tamansiswa University who had carried out field teaching practices as many as 98 people are then taken a sample of 86 people by random sampling. The data analysis technique is by calculating the percentage of achievement on the acquisition of each indicator. Measurement of value using categories (Always, Often, Rarely, and Never).

$$
\begin{gathered}
P=\frac{\mathrm{f}}{\mathrm{N}} x 100 \% \\
\text { Information: } \\
\mathrm{P}=\text { Percentage } \\
\mathrm{f}=\text { Number of values } \\
\mathrm{N}=\text { Total Value }
\end{gathered}
$$

(Indarti,2008) 
Table 1. digital literacy skill

\begin{tabular}{|c|c|c|}
\hline No & Digital literacy & Skills Performance \\
\hline 1 & Information literacy & $\begin{array}{l}\text { Access, assess and evaluate information data from the machine engineering } \\
\text { learning platform } \\
\text { Critically evaluate information from the internet / other digital sources } \\
\text { Use information accurately and creatively to solve problems } \\
\text { Managing information from various sources of technology platforms or } \\
\text { software for engineering learning }\end{array}$ \\
\hline 2 & ICT literacy & $\begin{array}{l}\text { Using ICT technology as a medium for learning, researching, evaluating, and } \\
\text { communicating information in machine engineering learning } \\
\text { Utilizing digital technology as a medium for accessing, managing, } \\
\text { integrating, evaluating, and producing information to acquire new knowledge } \\
\text { of mechanical engineering }\end{array}$ \\
\hline 3 & Media literacy & $\begin{array}{l}\text { Integrating technology media in mechanical engineering learning } \\
\text { create digital media in machine engineering learning } \\
\text { using digital media in accordance with the characteristics of the subjects } \\
\text { using digital media in accordance with the characteristics of students } \\
\text { carry out mixed learning (online and offline) using a specific platform }\end{array}$ \\
\hline
\end{tabular}

\section{Results \& Discussion}

The results of data processing from the research results can be presented as follows:

a. Information literacy

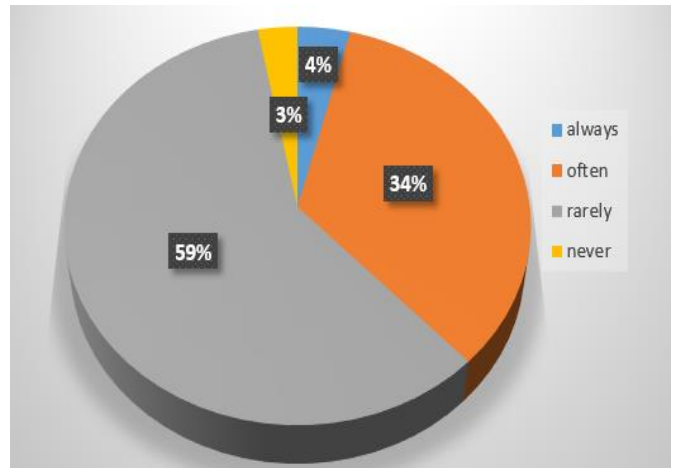

Figure 1. Pie chart students' profile of Information literacy

Based on Figure 1, students' abilities in information literacy can be obtained information that students in the rarely category (59\%) access information, use accurately, process, evaluate or critique information technology for the preparation of the learning process during teaching practice. Students who have information literacy competencies in the frequent category are $34 \%$.ICT literacy

b. ICT literacy

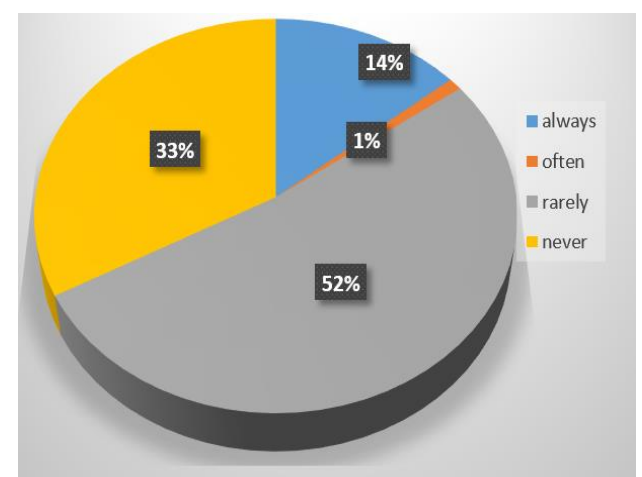

Figure 2. Pie chart students' profiles of ICT literacy 
Based on Figure 2, the students' ICT literacy abilities are in the category of never (1\%), rarely (52\%), often (33\%), and always (14\%) in this category the ability of students is measured on the integration of ICT-based media in learning, students design, using, managing, researching, evaluating ICT-based learning.

c. Media literacy

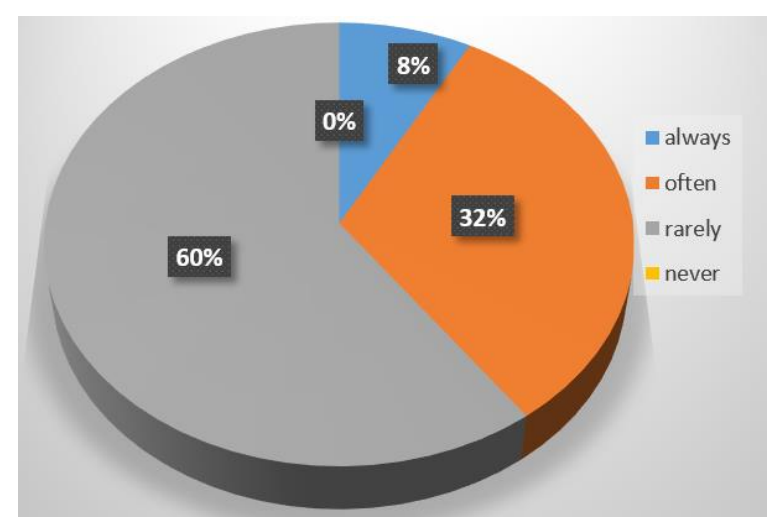

Figure 3. The Students' profile of media literacy

Based on Figure 3, the students' media literacy abilities are in the category of never $(0 \%)$, rarely $(60 \%)$, often $(32 \%)$, and always ( $8 \%$ ) in this category the ability of students is measured in the integration of media technology in learning, students design media, using media, developing, ICT-based media.

The three pie charts above, which are the results of research on students' digital literacy skills when carrying out field teaching practices (PPL) in schools, show that they are in a low category. This can be seen in the average of the three indicators of digital literacy skills of $57 \%$ in the rare category. Students who often take advantage of digital literacy in the learning process are $33 \%$. The large percentage of students who rarely integrate or utilize digital literacy in learning can predict that students are still low in their ability to digital competence. Based on the survey, students have information technology devices or devices such as laptops / PCs, based mobile phones (android, ios), easy internet access, support for devices they already have, which cannot be utilized in integrating ICT in learning during field teaching practices.

The expected abilities in information literacy are related to accessing, assessing, and evaluating information data from technical learning platforms, critically evaluating information from the internet / other digital sources, using information accurately and creatively to solve problems, managing information from various technology platform sources. or software for engineering learning. This ability is someone's skills in conducting internet-based information management with various existing platforms. the more skilled someone is in managing information, the more benefits he will get. Information literacy is also called information literacy, namely awareness of a person's information needs, identifying, accessing effectively efficiently, evaluating, and legally incorporating information into knowledge and communicating that information. (Janssen, at.al, 2013).. Information Literacy is the set of skills needed to find, retrieve, analyze, and use information. The twenty-first century has been named the information era, owing to the explosion of information and information sources. (Janssen, at.al, 2013).

Digital literacy skills in the ICT literacy indicators of students are expected to be able to use ICT as a medium for learning, researching, evaluating, and channeling information in learning, utilizing digital technology as a medium for accessing, managing, integrating, evaluating, and making information to obtain new knowledge both in their field and outside. Based on the results of research on this aspect, students rarely (55\%) make use of their devices to create ICT-integrated learning. Teachers must have the ICT skills needed to use technology to obtain learning resources outside their fields and pedagogical knowledge in strengthening professional learning. (Janssen, at.al, 2013).

Teachers' digital competence has been defined as the set of capacities and skills that result in the adequate incorporation and use of ICT as a methodological resource, integrated into the teaching-learning process, thus transforming ICT into Learning and Knowledge Technology (LKT) with a clear educational application. (Janssen, et.al, 2013).(Romero, et.al, 2020). The application of technological literacy can be done using the Personal Capability Matuarity Model (P-CMM) approach. Implementation can be done via computers, the internet, and cellular phones to introduce students to new knowledge.( Syarifuddin,2014).

Digital literacy skills on the student media literacy indicator are expected to have the competence to integrate technological media in learning, create digital media for machine engineering learning, use digital media according to the characteristics of subjects, use digital media according to student characteristics, carry out 
blended learning (online and offline). Students in carrying out teaching practices in schools have not used media literacy in learning. based on research results related to media literacy competencies, students rarely $(60 \%)$ integrate media in their learning. stressed that digital literacy requirements include competencies in finding, processing, producing, and communicating information, and it also implies fluency in online technologies, communication norms, and programming environments.( Radovanović,. et al ,2020). Media literacy needs to know what information and skills are needed for media literacy training and how they can be developed.(Erdem,2018). Students 'ability in digital literacy can create interesting learning and improve students' critical thinking. Learning designs by integrating ICT media will be more flexible, such as a solution to the covid 19 outbreak with online learning or blended learning. Media technology, especially new media, can change the way people learn, play, and socialize in the real world. Relating to something new requires new skills, especially as the subject facing is teenagers.(Fitryarin,2012).

Integrating media literacy media can help students achieve critical thinking. Good media literacy skills can improve critical thinking to analyze and provide opinions on phenomena during life.(Sudianto,2020; Falah,et.al, 2016). Very critical thinking in the industrial era 4.0. Teachers who can develop in the future is a teacher who masters information and communication technologybecause a lot of science and technology that can be accessed from this media.(siswanto,et.al 2013). Media / learning resources as a component learning segments are planned in a manner mature in the form of a learning design systematic.(midun,2016).

Digital literacy can create critical and creative mindsets and perspectives. Students can better map job opportunities in the industrialized world using digital-based information literacy, credibility, and quality, so that students do not easily receive negative information so that it can damage their mindset.(Sulianta,2020). The digital world can no longer be denied and avoided, solutions that need to be presented is to facilitate students in achieving digital literacy skills. Learning media are often used to help students improve understanding, present interesting and reliable data, facilitate data interpretation, and condense information.(Ratnawati,et.al, 2020; Setuju,et.al, 2018). concept of integrative curricular models of media education for students and teachers, which should take into account the need of analytical and reflective-assessment study of media or new information and communication technologies (ICT) more than their technical-instrumental aspect. (Vrabec, N. et.al, 2018).

\section{Conclusion}

Digital literacy skills have become a paradigm and reference in the life order of the 4.0 industrial revolution era. Digital literacy skills are competencies that are expected in the students of the Mechanical Engineering Vocational Study Program at the University of Sarjanawiyata to be improved, to deal with the learning needs of the 21st century. utilize and integrate ICT in learning. Learning outcomes that have been reserved by the Directorate General of Learning and Student Affairs of the Ministry of Research, Technology and Higher Education (2018) that in CPL it is recommended to include the skills needed in the industrial era 4.0 regarding data literacy, technological literacy, and a human literacy, as well as the ability to see signs there will be an industrial revolution 5.0. Digital literacy skills that are integrated with learning can facilitate students in critical thinking.

\section{References}

[1]. Darma, s. (2013). Tantangan guru SMK abad 21. Kemdikbud. Jakarta

[2]. Direktorat Jenderal Pembelajaran dan Kemahasiswaan,(2018). Buku Panduan Penyusunan Kurikulum Pendidikan Tinggi Edisi III. Direktorat Jenderal Pembelajaran dan Kemahasiswaan Kementeri. Ris. Teknol. dan Pendidik. Tinggi, vol. 53, no. 9, pp. 1689-1699

[3]. Erdem, (2018). The Importance of Placing Digital Media in Education. vol. 2018, no. 1, pp. 37-46

[4]. Falah, M. Komaro, and Yayat (2016). Penggunaan multimedia animasi untuk meningkatkan kemampuan berpikir kritis dalam pembelajaran materi bidang geser. J. Mech. Eng. Educ., vol. 3, no. 2, pp. 159-166, 2016, [Online]. Available: https://ejournal.upi.edu/index.php/jmee/article/viewFile/4545/3150

[5]. Fitryarini,L. (2014). Literasi Media Pada Mahasiswa Prodi Ilmu Komunikasi Universitas Mulawarman," pp. 51-67, 2014

[6]. Furchan, A.(2011). Pengantar Penelitian dalam Pendidikan. Yogyakarta: Pustaka Pelajar offset

[7]. Indarti, T. (2008). Penelitian Tindakan Kelas (PTK)dan Penulisan Ilmiah, Prinsip-Prinsip Dasar, Langkah-Langkah dan Implementasinya. Surabaya: FBS UNESA., 2008

[8]. Janssen, J., Stoyanov, S., Ferrari, A., Punie, Y., Pannekeet, K., \& Sloep, (2013). Experts' views on digital competence: Commonalities and differences. Comput. Educ., vol. 68, pp. 473-481., 2013

[9]. Johannesen, L. Øgrim, T. H. Giaever, and C. Scient.(2014). Nordic Journal Of Digital Literacy Notion in Motion: Teachers' Digital Competence," [Online]. Available: https://www.idunn.no/file/pdf/66738487/notion_in_motion_teachersdigital_competence_.pdf

[10]. Masitoh, S.(2018). Blended Learning Berwawasan Literasi Digital Suatu Upaya Meningkatkan Kualitas 
Pembelajaran dan Membangun Generasi Emas 2045. Proceedings of the ICECRS. Vol.1. No.3. pp. 1334. in Proceedings of the ICECRS, 2018, pp. 13-34

[11]. Midun,H. (2016). Penggunaan media pembelajaran menuju produktivitas belajar peserta didik," $J$. Pendidik. dan Kebud. Missio, vol. 8, no. 1, pp. 83-92. [Online]. Available: http://jurnal.unikastpaulus.ac.id/index.php/jpkm/article/view/88

[12]. Munir. (2014). Kerangka Kompetensi TIK Bagi Guru. Penerbit Alfabeta, Bandung

[13]. Radovanović,D. et al.,(2020). Digital Literacy Key Performance Indicators for Sustainable Development," vol. 8, no. 2, pp. 151-167. doi: 10.17645/si.v8i2.2587

[14]. Ratnawati, D. Mustafa Kusuma, Setuju.S., Nurtanto, and Widodo. (2020). Development of Job Sheet Lathe Machining Practice Based on Animation Video as Interactive Learning Media. J. Phys. Conf. Ser., vol. 1573, no. 1, 2020, doi: 10.1088/1742-6596/1573/1/012005.

[15]. Romero-garc and O. Buz. (2020). Improving Future Teachers ' Digital Competence Using Active Methodologies," pp. 1-15.

[16]. Setuju et al.(2018). Development e-learning to improve student activity with technological pedagogical and content knowledge. Int. J. Eng. Technol., vol. 7, no. 2.5 Special Issue 5.

[17]. Smaldino, et.al (2019). Instructional Technology and Media for Learning. Pearson. United States of America. ISBN 13: 978-0-13-428748-5

[18]. Siswanto R, Sugiyono, endang Suryaningsih, Sutopo, Irwanto, Jenny, Prasetyo Triatmojo, (2013). Tantangan guru SMK Abad 21. Kementerian Pendidikan dan Kebudayaan, 2013

[19]. Sudianto, Y.M. (2020). Peningkatan Keterampilan Berpikir Kritis Melalui Media Kliping Koran Dalam Pembelajaran Ips Sekolah Dasar," J. Inov. Penelit., vol. 1, no. 4, pp. 725-738. doi: 10.47492/jip.v1i4.140

[20]. Sulianta, F. (2020). Literasi Digital, riset, Perkembangan\&Perspekif sosial studies. Bandung.

[21]. Syarifuddin,S. (2014). Information and Communications Technology Literacy," J. Penelit. Komun., vol. 2 , p. 17 ,

[22]. Trilling and C. Fadel. (2009). Bernie Trilling, Charles Fadel-21st Century Skills_ Learning for Life in Our Times -Jossey-Bass (2009)," J. Sustain. Dev. Educ. Res., vol. 2, no. 1, p. 243.

[23]. UNESCO, (2018). Digital Literacy and Beyond," no. March, p. 11, [Online]. Available: https://www.unescap.org/sites/default/files/Digital literacy and beyond\%2C UNESCO.pdf

[24]. Vrabec, N. et.al (2018). Media Education and Teacher Training. Media Literacy and Academic Research. Vol 1. No 2 . 